\title{
Total Productive Maintenance and Manufacturing Performance: Does Technical Complexity in the Production Process Matter?
}

\author{
Halim Mad Lazim, Mohamed Najib Salleh, Chandrakantan Subramaniam, and Siti Norezam Othman
}

\begin{abstract}
This paper intends to discuss some findings from a study of TPM practices in manufacturing organizations in Malaysia. Total productive maintenance (TPM), a resource-emphasized approach moves the paradigm of maintenance by putting emphasis on total employee involvement in the maintenance activities. We studied the relationship between TPM practices and manufacturing performance. We investigated the moderating effect of the level of technical complexity in the production process in the TPM practices and manufacturing performance relationships as well. Significant relationships were found between TPM practices and cost. We also found the moderating effect of technical complexity in the production process on the relationship between TPM practices and manufacturing performance.
\end{abstract}

Index Terms-Cost, manufacturing, total productive maintenance.

\section{INTRODUCTION}

Total productive maintenance (TPM), a resource-emphasized approach moves the paradigm of maintenance by putting emphasis on total employee involvement in the maintenance activities. Operators and all employees should be actively involved in a maintenance programme that enable to avoid any disruptions, breakdowns, stoppages, failures, and so forth in order to improve manufacturing performance. Therefore, in the highly competitive manufacturing industries, the ability and reliability of equipment that well-maintained is very important in order to achieve desired manufacturing performance namely cost reduction, high quality products, on-time delivery, and flexibility. Furthermore, several studies in the literature argue that further research is required in the area of maintenance and operations management. In order to address this need, the study investigates the extent of TPM practices in the Malaysian manufacturing companies, to investigate the relationship between TPM practices and manufacturing performance and to investigate the moderating effect of the level of technical complexity in the production process in the TPM practices and manufacturing performance relationships. The study uses data collected from 106 manufacturing companies from various types of industries.

Manuscript received May 20, 2013; revised July 19, 2013. This work was supported in part by the Ministry of Higher Education of Malaysia under Fundamental Research Grant Scheme\#11878.

The authors are with the Universiti Utara Malaysia, School of Technology Management \& Logistics (e-mail: mlhalim@uum.edu.my, najib@uum.edu.my, chandra@uum.edu.my,norezam@uum.edu.my).

\section{LITERATURE REVIEW}

\section{A. Total Productive Maintenance}

Undeniably, new technologies and advanced equipment need more attention from manufacturing companies especially when there are strong demands and pressure from customers. Therefore, manufacturing companies need to respond quickly to ensure smooth daily operations and manage adjustments to uncertainties in the market place. The ability to produce products through lean production, for instance, requires an extraordinary workforce who is capable of dealing with various challenges. Through proper and suitable maintenance programmes, major losses due to breakdowns and defects can be avoided. Even though these maintenance program will cost money, but the lack of maintenance will cost even more [1]. The goal of the any TPM program is to improve productivity and quality along with increased employee moraleand job satisfaction. [2]. TPM has become more popular not only due to its ability to improve performance but also due to the emphasis it places on human capital resources. There are many recent worldwide studies (in the form of case studies and surveys) related to TPM, for example, [3]-[11].

\section{B. Technical Complexity in Production Process}

There are few researches being conducted to investigate the relationship between maintenance and technical complexity. Technical complexity has many definitions. In production process, it can be defined as the extent to which human effort is replaced by machines [12]. [13]claimed that increased technical complexity lead to greater control over the flow of processes and more predictable results for production. However, increased automation also means that equipment is more intricate making the diagnosis of equipment problems more difficult. . In a highly automated plant, the limitations of computer controls, the integrated nature of the equipment, and the increased knowledge requirements all make it more difficult to diagnose and solve equipment problems [14]. Type of production process in manufacturing can be divided into five categories; project, job shop, batch, assembly line and continuous flow [15]. However, in real manufacturing process, the effects of the different levels of technical complexity can be made plain by describing the characteristics of the end points of the scale, job-shop technology and continuous flow technology [16].

\section{Methodology}

We have surveyed Malaysian manufacturing companies 
using scientific approach. The sampling frame was taken from Federation of Malaysian Manufacturers (FMM) 2010 directory. The measures of this study were from various sources after thorough reviewed of articles. The sample selection was chosen systematically. The main objective of the study was to analyze the moderating effect of the level of technical complexity in the production process in the relationship between TPM practices and manufacturing performance. Then, the research hypothesis was tested using hierarchical regression analysis accordingly.

\section{RESUlts AND ANALYSIS}

There were 167 questionnaires returned back and usable responses were only $106(10.07 \%)$ and data was analyzed accordingly. In order to increase the response rate, efforts have been taken as suggested by [17] and [18]. We received $71(67 \%)$ responses from big companies and $35(33 \%)$ from small/medium companies. Most of the companies were operated more than 10 years. We also ran the factor analysis accordingly. All independent variables loadings were recorded more than 0.66 and Eigenvalues were more than 1.4. Meanwhile, the dependent variable, cost, recorded loadings of more than 0.7 and the Eigenvalue recorded were 8.56. Table I depicted the descriptive analysis for all variables.

TABLE I: DESCRIPTIVE ANALYSIS
\begin{tabular}{|l|c|c|}
\hline \multicolumn{1}{|c|}{ Variable } & Mean & Std. Dev. \\
\hline TPM team & 3.81 & 0.76 \\
\hline TPM strategy & 3.93 & 0.61 \\
\hline $\begin{array}{l}\text { Autonomous } \\
\text { maintenance }\end{array}$ & 3.91 & 0.63 \\
\hline Planned maintenance & 3.70 & 0.72 \\
\hline $\begin{array}{l}\text { Technology } \\
\text { Complexity }\end{array}$ & 3.53 & 0.78 \\
\hline Cost & 3.54 & 0.80 \\
\hline
\end{tabular}

The inter correlation of TPM team, TPM strategy, autonomous maintenance and planned maintenance indicated that there was a significant positive relationship with cost. The perceived reduction of manufacturing costs included production costs, manpower costs, overhead costs, material costs and unit costs. Thus, TPM team $(r=0.34, p<0.01)$, TPM strategy $(r=0.62, p<0.01)$, autonomous maintenance $(r=0.55, p<0.001)$ and planned maintenance $(r=0.57$, $p<0.01)$. Higher practices were associated with higher reduction of costs.

In order to examine the hypotheses of this study, 3-Step hierarchical regression was utilised. Various authors recommend using Hierarchical Regression in research concerned with moderator variable detection [19]-[21]. In addition, [22] suggest that moderating effect can be tested using multiple regressions. In step 1 , the 4 independent variables were regressed with the dependent variable.

In step 2, the moderator was included; technical complexity on production process was regressed with the dependent variable. Lastly, the independent variables, moderator and interaction of moderator, technical complexity on production process and independent variables were regressed with the dependent variable. However, before further analysis could proceed, multiple regression assumptions were tested accordingly. Multiple regressions rely on four main assumptions to be fulfilled. Normality, linearity, independence of residuals and homoscedasticity [23] and these were tested consequently.

The hierarchical regression showed TPM strategy $(\beta=$ $0.272, p<0.05)$ and planned maintenance $(\beta=0.437, p<0.01)$ were positively related to cost. Therefore, TPM strategy has a stronger prediction power of cost compared to planned maintenance. The significant interaction is between technical complexity and TPM strategy $(\beta=5.373, \quad p<0.01)$ and between technical complexity and planned maintenance $(\beta=-2.011, p<0.05)$.

Fig. 1 showed that the relationship between TPM strategy and cost is strongest in the case of high technical complexity and weakest in the case of low technical complexity.

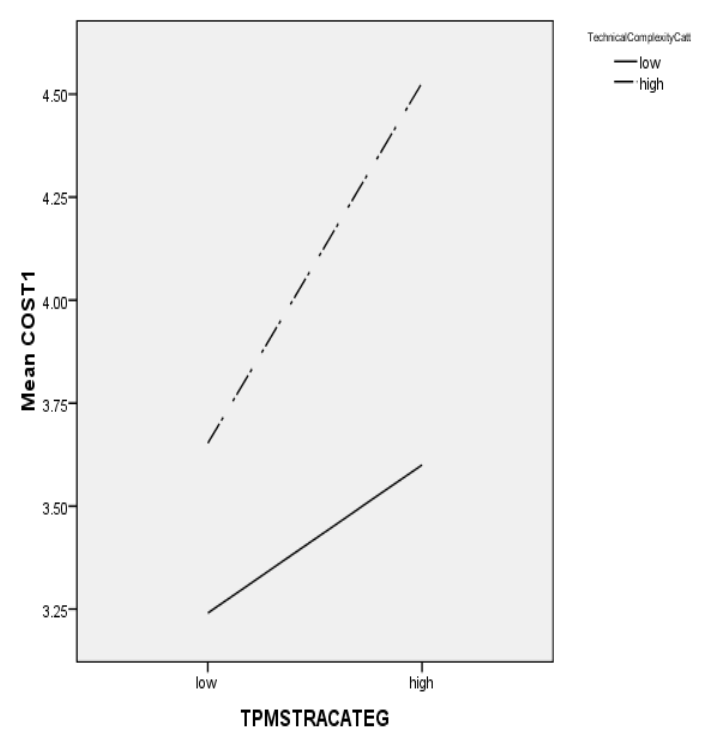

Fig. 1. The moderating effect of technical complexity in the relationship between Total Productive Maintenance (TPM) strategy and cost.

Meanwhile, Fig. 2 showed that technical complexity significantly moderates the relationship between planned maintenance and cost.

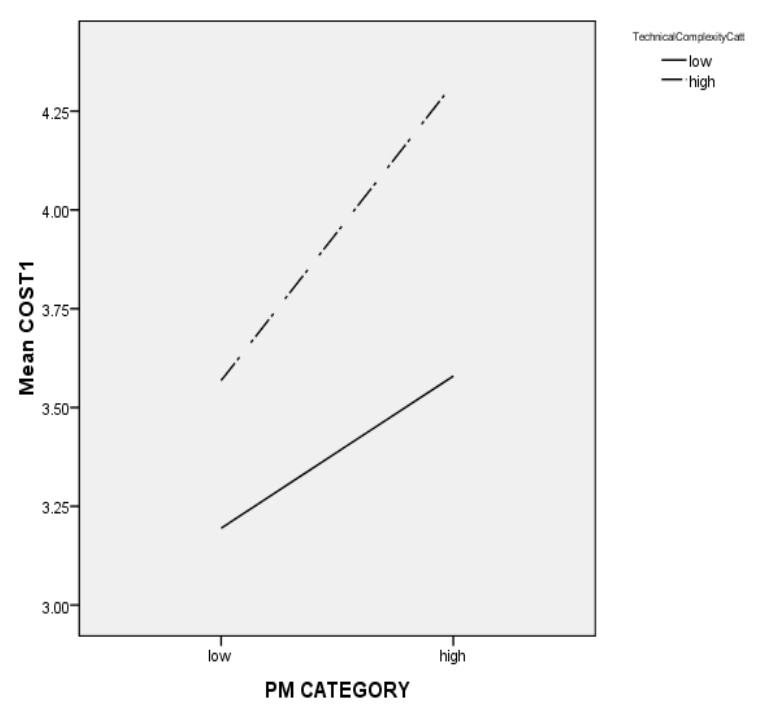

Fig. 2. The moderating effect of technical complexity in the relationship between Planned Maintenance and Cost. 


\section{CONCLUSION AND RECOMMENDATION}

TPM tries to ensure equipment related losses are minimized and more effort is made to reduce equipment-related losses or defects. TPM could essentially help to minimize the deterioration of equipment, hence improving performance as highlighted by various researchers, for instance, [4], [5], [24], [25], and [26]. Meanwhile TPM team usage in the plant being low as shown by the standardized beta value of -0.05 for cost. Furthermore, the vicariate analysis showed a moderate positive low correlation between TPM team and manufacturing performance, $r=0.34$, for cost. This relationship may not be strong enough to have held up in the multivariate analysis. As noted by [27] based on their case study, work habits and communication especially for production lines and different shifts could affect the morale of TPM team development. The possible assumptions to be drawn from this study are that the communication and leadership of TPM team are not clearly perceived by those at operator level and other departments. The TPM team has been perceived as unable to formulate actions that can effectively help to reduce costs. TPM strategy which focuses on overall equipment effectiveness (OEE) tries to demonstrate that using all related information and the production line status, operators and maintenance staff can work closely to ensure more improvement suggestions and to ensure well-functioning equipment, performance efficiency and availability of equipment. An overall OEE of $85 \%$ is considered as world class performance [28]. In order to achieve an OEE of $85 \%$, therefore, performance efficiency must achieve $95 \%$, availability must achieve $95 \%$ and quality must achieve $99 \%$. The results indicated that TPM strategy and planned maintenance found to be related to cost.

Future research can be expanded further by analyzing other factors contributed to manufacturing performance. For instance, product characteristics, vertical integration, model mix, automation level and market requirements might possibly affect manufacturing performance [29], [30] and [31].

\section{ACKNOWLEDGMENT}

H. M. Lazim, M. N. Salleh, C. Subramaniam, and S. N. Othman would like to express our grateful to the Ministry of Higher Education (MOHE), Research and Innovation Management Centre (RIMC) Universiti Utara Malaysia (UUM) and the Vice Chancellor of Universiti Utara Malaysia (UUM) in providing us the opportunity to conduct and finish this research.

\section{REFERENCES}

[1] A. Salonen and M. Deleryd, "Cost of poor maintenance: A concept for maintenance performance improvement," Journal of Quality in Maintenance Engineering, vol. 17, pp. 63-73, 2011.

[2] R. S. Singh, A. M. Gohil, D. B. Shah, and S. Desai, "Total Productive Maintenance (TPM) implementation in a machine shop: A case study," in Proc. Chemical, Civil and Mechanical Engineering Tracks of 3rd Nirma University International Conference on Engineering, 2012, pp. 592-599.

[3] H. M. Lazim and T. Ramayah,"Maintenance strategy in Malaysian manufacturing companies: a total productive maintenance (TPM) approach,"Business Strategy Series,vol. 11, no. 6, pp. 387-396, 2010.
[4] P. Tsarouhas, "Implementation of total productive maintenance in food industry: a case study," Journal of Quality in Maintenance Engineering, vol. 13,no. 1, pp. 5-18, 2007.

[5] I. P. S. Ahuja and J. S. Khamba, "An evaluation of TPM implementation in an Indian manufacturing enterprise," Journal of Quality in Maintenance Engineering, vol. 13, no. 4, pp. 338-52, 2007.

[6] I. P. S. Ahuja and J. S. Khamba, "Total productive maintenance: Literature review and directions," International Journal of Quality and Reliability Management, vol. 25, no. 7, pp. 709-756, 2008.

[7] O. S. Ohunakin, and R. O. Leramo, "Total productive maintenance in a beverage industry: A case study," Journal of Engineering and Applied Sciences, vol. 7, no. 2, pp. 128-133, 2012.

[8] K. Nahar, M. M. Islam, M. M. Rahman, and M. M. Hossain, "Evaluation of OEE for implementing Total Productive Maintenance (TPM) in sewing machine of a knit factory," in Proc. the Global Engineering, Science and Technology Conference, Dhaka, Bangladesh, December 28-29, 2012.

[9] M. W. Wakjira and A. P. Singh, "Total productive maintenance: A case study in manufacturing industry," Global Journal of Researches in Industrial Engineering, vol. 12, no. 1, pp. 25-32, 2012.

[10] M. Kaur, K. Singh, and I. S. Ahuja, "An evaluation of the synergic implementation of TQM and TPM paradigms on business performance," International Journal of Productivity and Performance Management, vol. 62, no. 1, pp. 66-84, 2013.

[11] I. P. S. Ahuja and P. Singh, "Application of analytical hierarchy process forjustification of TPM implementation in manufacturingOrganizations," International Journal Technology, Policy and Management, vol. 12, no. 1, pp. 37-47, 2012.

[12] J. G. Arca and J. C. P. Prado, "Personnel participation as a key factor for success in maintenance program implementation: a case study," International Journal of Productivity and Performance Management, vol. 57 ,no. 3, pp. 247-58, 2008

[13] L. Swanson, "An empirical study of the relationship between production technology and maintenance management,"International Journal of Production Economics, vol. 53, no. 2, pp. 191-207, 1997.

[14] J. Woodward, S. Dawson, and D. Wedderburn, Industrial Organization: Theory and Practice, London: Oxford University Press, vol. 3,1965 .

[15] D. A. Buchanan and J. Bessant, "Failure, uncertainty and control: the role of operators in a computer integrated production system," Journal of Management Studies, vol. 22, no. 3, pp. 292-308, 1985

[16] D. A. Collier, J. R. Evans and W. J. Stevenson, Operations Management, Nashville, TN: South Western Educational Publishing, 2008.

[17] D. A. Dillman, Mail and Internet Survey: the Tailored Design Method 2nd Ed., New York: John Wiley and Sons, 2000.

[18] D. Jobber, "Questionnaire factors and mail survey response rates,"EuropeanResearch, vol. 13, no. 3, pp. 124-129, 1985.

[19] L. S. Aiken and S. G. West, Multiple Regression: Testing and Interpreting Interactions, Newbury Park, CA: Sage Publication, 1991.

[20] J. Cohen and P. Cohen, Applied Multiple Regression Correlation Analysis for Behavioral Sciences, Hillsdale, NJ: Erlbaum, 1983.

[21] E. F. Stone-Romero and J. R. Hollenbeck, "Some issues associated with the useof moderated regression,"Organizational Behavior and Human Performance, vol. 34, no. 2, pp. 195-213, 1984.

[22] R. M. Baron and D. A. Kenny, "The moderator-mediator variable distinction insocial psychological research: conceptual, strategic and statistical considerations," Journal of Personality and Social Psychology, vol. 51, no. 6, pp. 1173-1182, 1986.

[23] J. F. Hair, R. E. Anderson, R. L. Tatham, and W. C. Black, Multivariate Dataanalysis, 5th Ed. Upper Saddle River, New Jersey: Prentice-Hall, 1998

[24] S. Ahmed, H. H. Masjuki, and Z. Taha, "TPM can go beyond maintenance: excerpt from a case implementation," Journal of Quality in Maintenance Engineering, vol. 11, no. 1, pp. 19-42, 2005.

[25] S. Ahmed, H. H. Masjuki, and Z. Taha, "TPM can go beyond maintenance: excerpt from a case implementation,"Journal of Quality in MaintenanceEngineering, vol. 11, no. 1, 19-42, 2005.

[26] D. Seth and D. Tripathi, "Relationship between TQM and TPM implementation factors and business performance of manufacturing industry in Indian context," International Journal of Quality and Reliability Management, vol. 22, no. 3, pp. 256-77, 2005.

[27] F. T. S.Chan, H. C. W. Lau, R. W. L. Ip, H. K. Chan, and S. Kong, "Implementation of total productive maintenance: a case study," International Journal of Production Economics, vol. 95, no. 1, pp. 71-94, 2005

[28] K. E. McKone, R. G. Schonberger, and K. O. Cua, "Total productive maintenance: a contextual view," Journal of Operations Management, vol. 17, no. 2, pp. 123-44, 1999. 
[29] R. Cooney, "Is 'lean' a universal production system? Batch production in theautomotive industry,"International Journal of Operations and ProductionManagement, vol. 22, no. 10, pp. 1130-1147, 2002.

[30] A. D. Toni and S. Tonchia, "Lean organization, management by process andperformance measurement,"International Journal of Operations andProduction Management, vol. 16, no. 2, pp. 221-236, 1996.

[31] R. R. Fullerton, C. S. M. Watters, and C. Fawson, "An examination of therelationships between JIT and financial performance," Journal of Operations Management, vol. 21, no. 4, pp. 383-404, 2003.

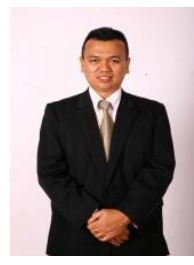

Halim Mad Lazim became a member of Asian Academy of Management (AAM). He was born on February 18, 1973. He was the youngest of ten children. Halim Mad Lazim is currently a senior lecturer at the School of Technology Management and Logistics in UUM. He teaches mainly courses in Operations Management such as Inventory Management, Supply Chain Management, Quality Management and others. Apart from teaching, he is a researcher as well in the area of technology and operations management.His publications have appeared in Business Strategy Series, American Journal of Industrial and Business Management, Malaysia Labor Review, International Review of Business Research Paper and various conferences proceedings. He is constantly invited to serve on the reviewing boards conferences of repute. He is also actively involved in short term research grants. He has completed research grants in the Total Productive Maintenance (TPM) and in the ISO 9000. He also has other ongoing research grants concerning the compression garment design for athlete, work safety, diabetic socks, and supply chain in the broiler industry.

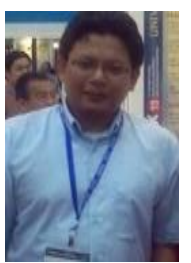

Mohamed Najib Salleh is a senior lecturer at the School of Technology Management and Logistics (STML) in Universiti Utara Malaysia (UUM). His research interest is in the area of Computer-Aided-Design and Manufacturing with specialization in garment technology. Najib obtained his degree from Tokyo Institute of Technology, Japan in 2000. He attained his Ph.D. in Manufacturing Engineering from LoughboroughUniversity in 2009. Currently he served as the deputy dean of STML.

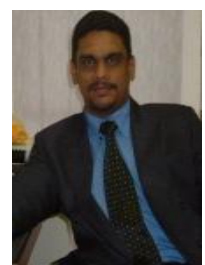

Chandrakantan Subramaniam received his bachelor and doctoral degree in Human Resource Management from Universiti Utara Malaysia in 2000 and 2009 respectively. He received his master's degree in Emergency Response and Planning in 2002. He has published a number of articles namely in Disaster Prevention and Management Journal, International Journal of Public Sector Management, Journal Pengurusan, to name a few.

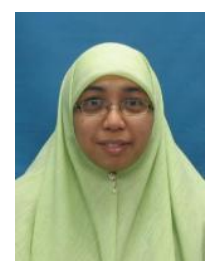

Siti Norezam Othman is an associate professor at School of Technology Management and Logistics, College of Business, Universiti Utara Malaysia. With nineteen years experiences in lecturing and research, she has lectured on subjects such as operations management and technology management for undergraduate and postgraduate students. Her research interests cover topics in supplier buyer relationships, purchasing and procurement, technology transfer, technology assessment, and operations management. She conducts research under various research grants from external agencies such as FRGS, RACE under Ministry of Higher Education, Institute of Health Management under Ministry of Health. Besides, she is invited as a facilitator for program conducted by government organization. In terms of industrial exposure, she was attached to Proton Berhad and Ingress Research SdnBhd for two years while completing her doctorate. She is invited to participate in a focus group in a number of workshops such as National Technology Road mapping for Machine and Tool Industry and Technology Foresight for Biotechnology organized by SIRIM. 